\title{
Level or Fraud and Professional Skeptisism to Become a Whistleblower
}

\author{
Henni Mande ${ }^{1}$, Mediaty Mediaty ${ }^{2}$, Abdul Hamid Habbe ${ }^{3}$, Kartini Kartini ${ }^{4}$ \\ ${ }^{1}$ (Accounting. STIE Panca Bhakti Palu, Indonesia) \\ 2,3,4, (Accounting, Hasanuddin University, Indonesia)
}

\begin{abstract}
This study aims to determine the effect of the level of fraud on the interests of government internal auditors to become whistleblowers and professional skepticism as a moderating variable. This study uses an experimental method with a total of 50 internal government auditors. The results showed that the level of fraud did not affect the interests of government internal auditors becoming whistleblowers and professional skepticism did not moderate the relationship between the two.
\end{abstract}

Keywords:- Whistleblower, Level of Fraud, Professional Skepticism.

\section{INTRODUCTION}

Fraud in the government environment has not subsided even more echoing and disrupting the lives of Indonesian people. Cheating on government agencies not only involves people who have high positions but also people who are below it, and not only occur in the central government environment but also the local government environment. Frauds that are often done include manipulating the recording of financial statements, omitting documents, and mark-up profits that can harm the country's finances or economy.

One way to prevent accounting violations so as to restore public confidence is to apply fraud inspection techniques where in forensic accounting is known as whistle-blowing or the use of whistleblowers (Merdikawati and Andry, 2012). Whistle-blowing is reporting done by members of an active or inactive organization regarding violations, illegal or immoral actions to parties inside and outside the organization (Khan, 2009).

The effectiveness of whistle-blowing in revealing fraudulent financial statements is not only recognized by accountants and regulators in the United States, but also in other countries (Patel, 2003). Given the important role of whistle-blowing in expressing financial fraud, understanding the factors underlying the intention to report fraud or misuse of assets is a very important topic (BameAldred et al., 2007).

Previous research relating to whistle-blowing interest has revealed some determinants of whistle-blowing interest. Several studies link situational factors such as the seriousness of fraud and the level of closeness (Kaplan and Whitecotton, 2001; Sabang, 2013; Winardi, 2013; Habbe, et al, 2017) as factors that also influence whistleblowing interest.

There are two elements that are definitely present in every fraud, namely the form of fraud (level of fraud) and perpetrators of fraud. Research using the concept of materiality in assessing the degree of cheating was carried out by Robinson et al. (2012) namely the misstatement of company costs. Errors $0.5 \%$ of the company's total costs are considered immaterial and misstatements of $6 \%$ of the company's total costs are considered material. The results of his research showed that respondents who consisted of members of the Institute of Internal Auditors (IIA) were less interested in reporting immaterial misstatements in the financial statements compared to material misstatements. Material misstatement can reduce the level of trust in financial information. In addition, material misstatement in the financial statements will harm the users of the financial statements.

In addition to situational or contextual factors, several studies link individual factors as factors that influence whistleblowing interests such as, ethical judgment (Ayers \& Kaplan, 2005), locus of control (Chiu, 2003), and organizational commitment (Somers \& Casal, 1994). Individual factors are factors inherent in a whistleblower. One of the causes of internal auditor failure in detecting fraud is the low level of skepticism of professional auditors (Beasley, Carcello and Hermanson, 2001).

Government internal audits (Inspectorate) as whistleblowers must be able to uncover all findings ranging from corruption, fraud, acts of violating laws or taxation, acts that can cause financial or non-financial losses, violations of standard operating procedures (SOP), ethical violations without any sense afraid to transfer positions, resulting in reporting that has an effect on audit quality (KNKG 2008). Internal auditors in carrying out their duties in the field in addition to following the audit procedures stated in the audit program the auditor must have professional skepticism.

Professional Standards for Public Accountants set limits on professional skepticism, namely the attitude of the auditor which includes the mind always questioning and evaluating critically on audit evidence (IAI, 2001, SA section 230.06). Skeptical internal auditors do not simply accept explanations from clients. to get objective information must ask questions to obtain reasons, evidence and confirmation of the object in question, in order to reveal the fraud that occurred. 
This research will focus on situational and individual factors. Situational factors as independent variables are the level of fraud and individual factors as moderating variables namely professional skepticism. The purpose of this study is to examine and analyze whether the level of fraud influences the interest in becoming a whistleblower and whether professional skepticism moderates the relationship of the influence of the level of cheating on an interest in becoming a whistleblower. This study is important because several previous studies, including Sabang (2013) and Habbe, et al (2017) have not used the variable of professional skepticism. The variable professional skepticism is still rarely found in whistleblowing research.

\section{LITERATURE REVIEW AND FORMULATION OF HYPOTHESES}

\section{> Prosocial Organizational Behavior Theory}

Sears, et al (1991) provide a fundamental understanding that each individual is not solely a single creature capable of living alone, but as a social creature that is highly dependent on other individuals, individuals cannot enjoy a normal and happy life without a social environment. Someone is said to behave prosocial if the individual is helping other individuals regardless of the motives of the helper, arises because of the suffering experienced by others which includes mutual help, mutual comfort, friendship, salvation, sacrifice, generosity, and sharing.

Myers (2012) states that prosocial behavior or altruism is the desire to help others without thinking about their own interests. Prosocial behavior can be understood as behavior that benefits others. Concretely, the understanding of prosocial behavior includes sharing, cooperation, helping, honesty, generousity and considering the rights and welfare of others (Mussen, 1982). Prosocial behavior is a theory that supports whistle-blowing. Brief and Motowidlo (1986) mention whistleblowing as one of 13 forms of prosocial organizational behavior. Prosocial behavior theory has several antecedent variables which are grouped into two large groups namely Individual and contextual.

Based on the explanation above, the aspects of prosocial behavior used in this study are acting honestly, helping, and saving. The degree of cheating is contextual antecedent and professional skepticism is individual antecedent.

\section{Whistleblowing}

Miceli and Near (1985) define whistleblowing is a disclosure by members of an organization about illegal, immoral or illegitimate practices under the control of their superiors to people or organizations that can influence actions. Whistleblowing can also be defined as the efforts of current or past members of an organization to give warnings to the organization's top management or to the public about a serious mistake made or hidden by the organization (Ahern and McDonald, 2002; Putri, 2016).
Individuals who do whistleblowing are called whistleblowers, Miceli and Near (1985) explain that what can be called a whistle-blower have four characteristics, namely (1) employees or former employees of an organization whose organization is cheating; (2) does not have authorization to change or stop the fraud under its control; (3) allowed or not allowed to make a report; (4) does not occupy a position whose job requires the reporting of corporate fraud.

\section{$>$ Level / Seriousness of Fraud and Interest in WHistleblowing}

Material misstatement can reduce the level of trust in financial information. In addition, material misstatement in the financial statements will harm the users of the financial statements. Some previous studies use quantitative perspectives to measure the seriousness of fraud as conducted by Schultz (1993), Menk (2011), and Robinson et al (2012) who apply the concept of materiality in the accounting context so that the seriousness of fraud is measured based on variations in the value of wrongdoing / fraud / loss. This quantitative perspective is the easiest approach to do because the indicators are clear, measurable and easily observable.

Menk (2011), Sabang (2013), Winardi (2013), Bagustianto and Nurkholis (2015) produce evidence that the level of seriousness of wrongdoing has a significant positive effect on whistleblowing interest. Different results are shown from Kaplan and Whitecotton (2001) and Habbe, et al (2017) research that the perception of seriousness assessment is not related to the auditor's interest in reporting questionable behavior. Inconsistent findings indicate that research related to the level of cheating and whistleblowing still needs to be done.

One of the prosocial behaviors is trying to make improvements to the organization (Brief and Motowildo, 1986). One form of improvement is to keep the information presented trustworthy by users of financial statements. Another behavior of someone who is prosocial is to provide the best service to those in need (Brief and Motowildo, 1986), acting honestly giving correct information to users of financial reports and saving state money is one form of implementing prosocial behavior. Based on the theory of prosocial behavior and research, the proposed hypothesis is:

H1: Internal auditor's interest in becoming a whistleblower is greater if the level of fraud is high than the level of fraud is low

\section{> Professional Skepticism and Interest in Whistleblowing}

Fullerton and Durtschi (2004) found that auditors who have high professional skepticism will make the auditor always look for more and more significant information than auditors who have low professional skepticism, and this results in auditors who have high levels of professional skepticism more potentially detect fraud (fraud) because of the additional information they have. The opportunity to 
detect fraud can increase the interest of internal auditors in conducting whistleblowing.

Based on investigators' research, there are still few studies examining the effect of professional skepticism on whistleblowing. Puspita et al (2017) find that professional skepticism influences whistleblowing intentions. This means that the higher the auditor's professional skepticism, the auditor has a tendency to take wish-blowing actions. Based on the explanation above, this study proposes a hypothesis:

H2: There is a difference in internal auditor's interest in becoming a whistleblower between low and high professional skepticism based on the level of fraud.

\section{RESEARCH METHODS}

\section{- Experimental Design}

The experimental model between subject designs is used to determine differences in internal auditor interest at each level of fraud. Between subject design is used to avoid the demand effect that is the subject knows the direction of the condition or treatment given. Between subject designs will compare the effect of different treatments on different subjects, where each subject gets one case exposure (Habbe and Mande, 2016).

Participants or subjects will be divided into 2 groups with different treatments based on a questionnaire. The first group was given the Low Fraud Rate (TKR) case treatment and the second group was given the High Fraud Rate case treatment. All respondents received a professional skepticism questionnaire. Research instruments in the form of cases or scenarios and professional skepticism questionnaires were sent to the Wajo Regency Inspectorate office and Makassar Municipality.

\section{$>$ Research Subjects}

The subject of this study was the government internal auditor at the Wajo Regency inspectorate office and Makassar Municipality, South Sulawesi Province. Internal auditors at the Inspectorate of Wajo Regency received 25 respondents for the Low Fraud Rate (TKR) case and in the Makassar Municipality Inspectorate accepted 25 cases of High Fraud (TKT) cases.

Habbe (2006) states that there is no clear benchmark of how many participants are in an experiment, but the basic law applies that the larger the sample the better because the power of the test increases. Based on several studies that became the reference of this study, the number of subjects in one group or group was 25 people, the total number of subjects or respondents in this study were 50 people.

\section{$>$ Operational Definitions}

\section{- Case Design Level of Fraud}

The scenario or case presented to respondents shows the Fraud Level (TK) which is divided into two levels, namely Low Fraud Level (TKR) and High Fraud Level (TKT). The types of fraud in the first and second cases are the same, namely overpayment of honorariums. However, the degree of materiality of cheating is different. The modification in both cases is the level of materiality of cheating by referring to the research of Robinson et al. (2012). The level of materiality in the first case is $0.5 \%$, whereas in the second case it is $6 \%$ of the total budget. Another modification is the year of events and the context of fraud in the public sector (local government).

Randal and Gibson (1990) suggest that the scenarios developed should pay more attention to realistic conditions to reduce the problem of ambiguity and obscurity. Realistic scenarios allow respondents to put themselves in the position of the characters depicted in the scenario (Patel, 2003). The case used in this experiment is the findings of the local government internal auditor.

\section{- Professional skepticism}

Hurtt, Eining, and Plumlee (2003) have built a model that can describe the problem of professional skepticism in the context of financial statement audits. The model they made said that auditor's professional skepticism consisted of 6 characteristics, namely:

$\checkmark$ The mind that is always asking questions

$\checkmark$ Not making decisions quickly

$\checkmark$ Always find out

$\checkmark$ Understand between individuals

$\checkmark$ Confidence, and

$\checkmark$ Have courage.

Then these six things will bring an auditor to an increase in skepticism, namely an increase in additional search terms, detection of contradictions, alternative things that might occur, and careful research on the reliability of a source. Professional skepticism is divided into two namely high professional skepticism and low professional skepticism based on the score of each respondent.

\section{Data Analysis Method}

The first step before testing the hypothesis is to conduct a descriptive analysis by comparing the demographic characteristics of gender. It aims to determine the composition of the two groups. In testing hypothesis 1 the parametric analysis tool used to compare is the independent sample t-test and for testing hypothesis 2, the analysis tool used is Anova Two Way.

Independent sample $\mathrm{t}$ test is used to test whether there is a difference between the level of cheating against interest. Anova Two Way is used to test whether professional skepticism moderates the relationship of the level of cheating to the interest of being a whistleblower. 


\section{DATA ANALYSIS}

\section{Research Respondents}

The questionnaire collected as many as 50 .

\begin{tabular}{|c|c|c|}
\hline Group & Gender & Total \\
\hline TKR & Man & 11 \\
\hline TKT & Woman & 14 \\
\hline & Man & 15 \\
\hline & Woman & 10 \\
\hline
\end{tabular}

Table 1:- Demographics

\section{Analysis}

- Hypothesis Testing 1

Hypothesis 1 testing is conducted to prove that the interest of internal auditors becoming a whistleblower is greater if the level of fraud is high compared to the level of fraud that is low. The analytical tool used for testing Hypothesis 1 is the independent sample t test and the data being compared, namely the interest of internal auditors into whistleblowers when the level of fraud is low and when the level of fraud is high.

\begin{tabular}{|l|c|c|c|c|c|}
\hline \multicolumn{2}{|c|}{ Keterangan } & N & Mean & $\begin{array}{c}\text { Std. } \\
\text { Deviation }\end{array}$ & $\begin{array}{c}\text { Std. Error } \\
\text { Mean }\end{array}$ \\
\hline \multirow{2}{*}{$\begin{array}{l}\text { Minat menjadi } \\
\text { Whistleblower }\end{array}$} & $\begin{array}{c}\text { Kecurangan } \\
\text { Rendah }\end{array}$ & 25 & 5,08 & 1,152 &, 230 \\
\cline { 2 - 5 } & $\begin{array}{c}\text { Kecurangan } \\
\text { Tinggi }\end{array}$ & 25 & 5,60 & 1,384 &, 277 \\
\hline
\end{tabular}

Table 2:- Difference in Average Interest in Becoming a Whistleblower based on Fraud Rate

\begin{tabular}{|c|c|c|c|c|c|c|c|c|c|c|}
\hline & & \multicolumn{2}{|c|}{$\begin{array}{l}\text { Levene's } \\
\text { Test for } \\
\text { Equality of } \\
\text { Variances }\end{array}$} & \multicolumn{7}{|c|}{ t-test for Equality of Means } \\
\hline & & \multirow[t]{2}{*}{$\mathrm{F}$} & \multirow[t]{2}{*}{ Sig. } & \multirow[t]{2}{*}{$\mathrm{t}$} & \multirow[t]{2}{*}{ df } & \multirow[t]{2}{*}{$\begin{array}{l}\text { Sig. } \\
(2- \\
\text { tailed })\end{array}$} & \multirow[t]{2}{*}{$\begin{array}{c}\text { Mean } \\
\text { Differences }\end{array}$} & \multirow[t]{2}{*}{$\begin{array}{c}\text { Std. } \\
\text { Error } \\
\text { Differences }\end{array}$} & \multicolumn{2}{|c|}{$\begin{array}{c}95 \% \\
\text { Confidence } \\
\text { Interval of the } \\
\text { Difference }\end{array}$} \\
\hline & & & & & & & & & Lower & Upper \\
\hline \multirow{2}{*}{$\begin{array}{c}\text { Minat } \\
\text { Menjadi } \\
\text { Whistleblower }\end{array}$} & $\begin{array}{c}\text { Equal } \\
\text { Variances } \\
\text { assumed }\end{array}$ & ,838 & ,364 & $\begin{array}{c}- \\
1,444\end{array}$ & 48 &, 155 &, 520 &, 360 & $-1,244$ &, 204 \\
\hline & $\begin{array}{c}\text { Equal } \\
\text { Variances } \\
\text { Not } \\
\text { assumed } \\
\end{array}$ & & & $\begin{array}{c}- \\
1,444\end{array}$ & 46,462 & , 156 & ,520 & ,360 & $-1,245$ & ,205 \\
\hline
\end{tabular}

Table 3:- Different Tests The Effect of Fraud Levels on Interest in Becoming a Whistleblower

Based on table 2 above, the average interest in becoming a whistleblower at a high cheating rate is greater than at a low cheating level. The average whistleblower interest at the high cheating rate was 5.60 while at the low cheating level it was 5.08 .

Based on the results of the independent sample $t$ test in table 3, the $t$ value is 1.444 with a p-value of 0.155 . Because the probability is greater than 0.05 , this means that the average between interest in becoming a whistleblower at a low cheating rate and a high cheating rate is no different. In other words, there is no difference in interest in becoming a whistleblower between high and low fraud levels. The results of this statistical test do not support hypothesis 1. 
- Hypothesis Testing 2

\begin{tabular}{|c|c|c|c|}
\hline \multicolumn{5}{|c|}{ Levene's Test of Equality of Error Variances $^{\text {a }}$} \\
\hline \multicolumn{5}{|c|}{ Dependent Variable: WHISTLEBLOWING } & Sig. \\
\hline F & df1 & 46 &, 136 \\
\hline 1,941 & 3 & df2 & \\
\hline
\end{tabular}

Table 4

Levene's test results show that the F count is 1.941 and the Sig value is 0.136 . Because the value of $p>0.05$ means the null hypothesis is accepted. The results of this test indicate that the population has significantly the same variance.

\begin{tabular}{|c|c|c|c|c|c|}
\hline \multicolumn{7}{|c|}{ Tests of Between-Subjects Effects } \\
\hline & $\begin{array}{c}\text { Dependent Variable: WHISTLEBLOWING } \\
\text { Type III Sum of } \\
\text { Squares }\end{array}$ & df & Mean Square & F & Sig. \\
\hline Source & $5,006^{\text {a }}$ & 3 & 1,669 & 1,007 &, 398 \\
\hline Corrected Model & 1397,538 & 1 & 1397,538 & 843,500 &, 000 \\
\hline Intercept & 4,070 & 1 & 4,070 & 2,456 &, 124 \\
\hline TINGKATKECURANGAN & 1,256 & 1 & 1,256 &, 758 &, 388 \\
\hline SKEPRO &, 388 & 1 &, 388 &, 234 &, 631 \\
\hline KECURANGAN * SKEPRO & 76,214 & 46 & 1,657 & & \\
\hline Error & 1507,000 & 50 & & & \\
\hline Total & 81,220 & 49 & & & \\
\hline
\end{tabular}

Table 5

Anova test results above indicate that the level of cheating gives an $\mathrm{F}$ value of 2.456 and is significant at 0.124 ( $p>0.05$ ). This means that there is no significant difference in the average interest in becoming a whistleblower based on the level of fraud. Professional skepticism gives an $\mathrm{F}$ value of 0.758 and a significant value of 0.388 ( $p>0.05)$. This means that there is no significant difference between the average professional skepticism based on the level of cheating.

The results of the interaction between the level of cheating and professional skepticism gave an $\mathrm{F}$ value of 0.234 and a significant value of 0.631 ( $p>0.05$ ). This means that there is no joint effect between the level of cheating and professional skepticism on the average interest in becoming a whistleblower. Professional skepticism does not moderate the influence of fraud on the auditor's interest in becoming a whistleblower. Hypothesis 2 is not supported. The RSquare Adjust of 0.267 means that the variability of interest into a whistleblower that can be explained by variables of the level of cheating, professional skepticism, and the interaction between the level of cheating and professional skepticism is $26.7 \%$.

\section{DISCUSSION}

Hypothesis 1 states that internal auditor's interest in becoming a whistleblower is greater if the level of fraud is high compared to the level of fraud that is low. The results of hypothesis testing statistically prove that $\mathrm{H} 1$ is not supported.
The results of this study are in line with research by Kaplan and Whitecotton (2001) and Habbe, et al (2017). Kaplan and Whitecotton (2001) found that perceived seriousness perceptions were not related to the auditor's interest in reporting questionable behavior from his coworkers. Habbe, et al (2017) measure cognitive moral development and test their interactions with antecedents of prosocial behavior, one of which is the level of fraud, in influencing the desire of local government internal auditors (APIP) to become whistleblowers. Their results showed no significant difference between the variants of the level of cheating.

Habbe, et al (2017) state that the level of fraud that does not affect the auditor's interest in whistleblowing is likely due to the high organizational commitment to the internal auditor so that any form of fraud will be reported regardless of the level of fraud low or high.

Hypothesis 2 states that there are differences in internal auditor interest in becoming a whistleblower between low and high professional skepticism based on the level of fraud. Hypothesis 2 test results are not supported. Professional skepticism does not moderate the influence of the level of fraud on the interest of internal auditors as whistleblowers.

Puspita et al (2017) find that professional skepticism influences whistleblowing intentions. This means that the higher the auditor's professional skepticism, the auditor has a tendency to take wish-blowing actions. However, this 
study uses professional skepticism as a moderating variable while Puspita et al (2017) uses professional skepticism as an independent variable. There are very few whistleblowing studies that use professional skepticism variables so that this study has difficulty making comparisons between previous research findings.

\section{CONCLUSION}

Tests in this study found that the interests of government internal auditors as whistleblowers in conditions of high and low fraud levels were not different or the same. This could be due to the high independence and commitment of the organization's internal government auditors so that they will report fraud without differentiating between high and low fraud levels.

Professional skepticism does not moderate the influence of the level of fraud on the interests of government internal auditors to become whistleblowers. Professional skepticism does not moderate the influence of the level of cheating and interest in becoming a whistleblower can be caused by the absence of the influence of the level of cheating on the interest of being a whistleblower.

\section{LIMITATIONS AND SUGGESTIONS}

This study has several limitations that might affect the results of the study. These limitations include, first, this study uses a quasi-experimental model so that randomization of group variable determination is not carried out. Future studies are recommended using laboratory experiments. Second, further research is suggested to use the variable organizational commitment as an individual factor.

\section{ACKNOWLEDGEMENTS}

Thanks to the University of Hasanuddin and LPDP DIKTI that has funded this research, therefore this research have broud impact on the economy and welfare of the people of Indonesia.

\section{REFRENCES}

[1]. Ahern, K. M. dan S. McDonald. 2002. The Beliefs of Nurses Who Were Involved in A Whistleblowing Event, Journal of Advanced Nursing, 38 (3), 303-309.

[2]. Ayers, Susan dan Steven E. Kaplan. 2005. Wrongdoing by Consultants: AnExamination of Employees' Reporting Intentions. Journal of BusinessEthics. Vol. 57. Pp. 121-137.

[3]. Bagustianto, Rizki, dan Nurkholis. (2015). Faktorfaktor yang mempengaruhi minat pegawai negeri sipil (pns) untuk melakukan tindakan whistleblowing (studi pada PNS BPK RI). Jurnal Ilmiah Mahasiswa Feb. Vol 3 (1) : 1411 - 0393.

[4]. Bame-Aldred, C., Sweeney, J, T., and Seifert, D. 2007. An Examination of The Effectiveness of
Sarbanes-Oxley Whistleblower Protection. Journal of Forensic Accounting. Vol 8, pp. 105-118.

[5]. Beasley, M.S., Carcello, J.V., and Hermanson, D.R. “Top 10 Audit Deficiencies." Journal of Accountancy (April 2001): 63-66.

[6]. Brief, Arthur P dan Stephan J. Motowidlo. 1986. Prosocial Organizational Behaviors. The Academy of Management Review. Vol. 11. No. 4. Pp. 710-725.

[7]. Chiu, R. K. 2003. Ethical judgment and whistleblowing intention: Examining the moderating role of locus of control. Journal of Business Ethics 43: 65-74.

[8]. Fullerton, Rosemary, and Cindy Durtschi. "The Effect of Professional Skepticism on the Fraud Detection Skills of Internal Auditors.” Working Paper, 2005.

[9]. Habbe, Abdul Hamid. 2006. Pengujian Heuristik Representativeness dan Anchoring Adjustment atas perilaku Over/Underreaction investor terhadap informasi laba, dan konsekuensinya pada prediksi laba dan penilaian saham. Disertasi. Perpustakaan pusat UGM.

[10]. Habbe, A.H, Alimuddin, A. Kusumawati, A. Rura, Y. 2017. Cognitive Moral Development, Organizational Situation, and Ethical Decision Making in Business and Accounting. Working Paper.

[11]. Habbe, A.H, and Mande, H. 2016. The Effect Of Information Sequential And Personality On The Investor Belief Revision (An Experimental Study In Decision Making). Ponte, International Scientific Researches Journal. Vol. 72 (10). 150-166

[12]. Hurtt, K., Eining, M. \& Plumlee, D. "Professional Scepticism: A Model with Implication for Research, Practice, and Education." Working Paper, University of Wisconsin, 2003.

[13]. Kaplan, Steven E. dan Stacey M. Whitecotton. 2001. An Examination of Auditors' Reporting Intentions When Another Auditor Is Offered Client Employment. Auditing: A Journal of Practice and Theory. Vol. 20. No. 1. Pp. 45-63.

[14]. Khan, M.A. 2009. Auditors and Whistleblowing Law. Accountant Today. April 2009, pp. 12-14.

[15]. Menk, K. B. 2011. The impact of materiality, personality traits, and ethical position on whistleblowing intentions. Dissertation, Department of Accounting, Virginia Commonwealth University, Harrisonburg.

[16]. Merdikawati, Risti dan Andry Prastiwi. 2012. Hubungan Komitmen Profesi dan Sosialisasi Antisipatif Mahasiswa Akuntansi Dengan Niat Whistleblowing. Diponegoro Journal of Accounting. Volume 1, Nomor 1, Tahun 2012, halaman 1-10.

[17]. Mussen, P. (1982) Personality Development and Liberal Sociopolitical Attitudes. In: N. Eisenberg (ed.) The Development of Prosocial Behavior. New York: ACADEMICPRESS, INC. Page 363.

[18]. Myers, David G. (2012). Psikologi Sosial Jilid 2. Jakarta: Salemba Humanika.

[19]. Near, J. P., \& Miceli, M. P. (1985). Organizational dissidence: The case of whistleblowing.Journal of Business Ethics 4(1), 1-16. 
[20]. Patel, Chris. 2003. Some Cross-Cultural Evidence on Whistle-Blowing as an Internal Control Mechanism. Journal of International AccountingResearch. Vol. 2. Pp. 69-96.

[21]. Puspita, dkk. 2017. Pengaruh Skeptisisme Profesional dan Etika Terhadap Whistleblowing Auditor Inspektorat di Provinsi Bengkulu. Masters Thesis. Universitas Bengkulu. UNIB Scholar Repository.

[22]. Putri, C. M. 2016. Pengaruh Jalur Pelaporan dan Tingkat Religiusitas terhadap Niat Seseorang Melakukan Whistleblowing. Jurnal Akuntansi dan Investasi, 17 (1), 42-52.

[23]. Randall, D.M. dan A.M. Gibson. 1990. Methodology in Business Ethics Research: A review and Critical Assessment. Journal of Business Ethics. Vol. 9. Pp. 457-471.

[24]. Robinson, Shani N; Jesse C. Robertson; dan Mary B. Curtis. 2012. 2012. The Effect of Contextual and Wrongdoing Attibutes on Organizational Employees' Whistleblowing Intentions Following Fraud. Journal ofBusiness Ethics. Vol. 106. Pp. 213-227.

[25]. Sabang, M. I. 2013. Kecurangan, Status Pelaku Kecurangan, Interaksi Individu- Kelompok, dan Minat Menjadi Whistleblower (Eksperimen pada Auditor Internal Pemerintah. Tesis. Program Pasca Sarjana Fakultas Ekonomi dan Bisnis Universitas Brawijaya. Malang.

[26]. Schultz, Joseph J, Jr.; Douglas A. Johnson; Deigan Morris; dan Sverre Dyrnes. 1993. An Investigation of The Reporting of Questionable Acts in An International Setting. Journal of Accounting Research. Vol. 31. Pp. 75-103.

[27]. Sears, D.O; Fredman, J.L., dan Peplau, L. A. (1991). Psikologi sosial. Jilid 2. Alih Bahasa: Michael Adryanto. Jakarta: Erlangga.

[28]. Somers, M., J, and J. C. Casal. 1994. Organizational commitment and whistleblowing Group and Organizational Management 19: 270-283.

[29]. Winardi, Rijadh Djatu. 2013. The Influence of Individual and Situational Factors on Lower-Level Civil Servantse ${ }^{\text {ee }}$ Whistle-Blowing Intention in Indonesia. Journal of Indonesian Economy and Business. Vol. 28 (3); 361-376. 